\title{
Seroprevalence of Toxoplasma gondii in aborted goats in Kerala
}

\author{
R. Karthika1', K. Devada², Bindu Lakshmanan ${ }^{3}$, \\ K. Syamala ${ }^{4}$, K. Vijayakumar ${ }^{5}$ and G.M. Pooja ${ }^{6}$ \\ Department of Veterinary Parasitology, College of Veterinary and Animal Sciences \\ Kerala Veterinary and Animal Sciences University \\ Mannuthy, Thrissur, Kerala - 680651 , India.
}

Citation: Karthika, R., Devada, K., Lakshmanan, B., Syamala, K., Vijayakumar, K. and Pooja, G.M. 2021. Seroprevalence of Toxoplasma gondii in aborted goats in Kerala. J. Vet. Anim. Sci. 52(2): 166-170. DOI: https://doi.org/10.51966/jvas.2021.52.2.166-170

Received:21.12.2020

Accepted: 22.01.2021

Published: 01.06.2021

\begin{abstract}
Toxoplasmosis, is a cosmopolitan zoonotic parasitic infection prevalent throughout the world affecting all warm blooded animals and man. A total of 72 serum samples from goats belonging to the organised, unorganised and small holder farms that had aborted recently or had a history of abortion were collected from the central districts of Kerala viz., Palakkad, Thrissur and Ernakulam. The samples were subjected to indirect Enzyme Linked Immunosorbent Assay (ELISA) for the detection of $\lg G$ antibodies of Toxoplasma gondii. Factors predisposing to the prevalence of infection such as age, grazing behaviour and stage of gestation were also taken into account during the study. Out of 72 serum samples examined, 31(43 per cent) were negative, 13 (18 per cent) were weakly positive and 28 (38.88 per cent) were highly positive. A higher prevalence was noticed in goats above four years of age, in those with regular grazing behaviour and in those that had aborted in the second stage of gestation. District-wise prevalence revealed relatively higher prevalence in Ernakulam district (62.5 per cent) compared to Thrissur (56.09 per cent) and Palakkad (53.33 per cent), even though the difference was not statistically significant.
\end{abstract}

Keywords:Toxoplasma gondii, Enzyme Linked Immunosorbent Assay, Goat, Kerala.

Toxoplasmosis is a wide spread zoonotic protozoan parasitic infection caused by T. gondii capable of infecting both mammals and birds (Dubey and Beattie, 1998). Felids are the definitive host and following infection they shed oocysts in the faeces. While most of the intermediate

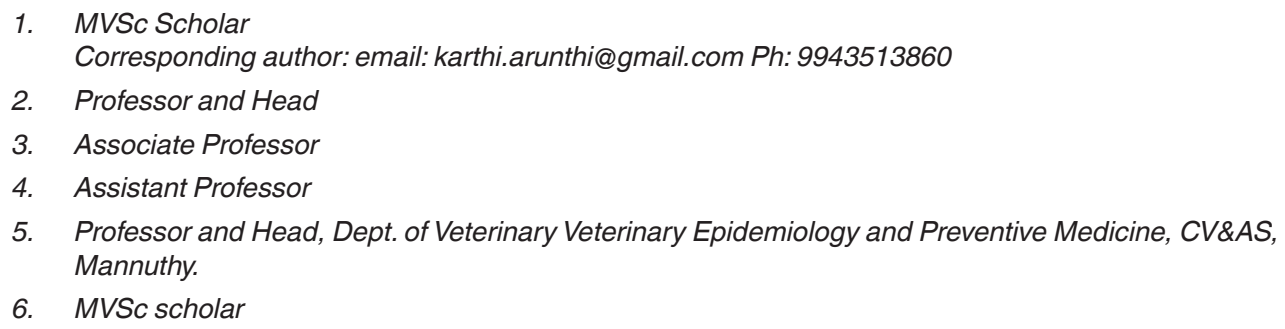

Copyright: ( ) 2021 R. Karthika et al. This is an open access article distributed under the terms of the Creative Commons Attribution 4.0 International License (http://creativecommons.org/licenses/by/4.0/), which permits unrestricted use, distribution, and reproduction in any medium, provided the original author and source are credited.

166 Seroprevalence of Toxoplasma gondii in aborted goats in... 
hosts remain asymptomatic, toxoplasmosis is acute in sheep and goats causing resorbtion, abortion, foetal mummification and still birth (Ahmed et al., 2008). Goats become infected when they feed on pastures, concentrates or drinking water contaminated with $T$. gondii oocysts. Toxoplasmosis associated abortions significantly affect the reproductive status of the goats, eventually leading to decreased production and productivity. It also poses a major threat to humans because of its zoonotic importance. Reports on the prevalence of toxoplasmosis and Toxoplasma associated abortions in food animals especially in goats are scarce in India, although there are a few studies on the seroprevalence of the disease in this species. Due to the significance of T.gondii in public health and economic points of view, there is an urgent need for early and accurate detection of the disease. This will help to map the seroprevalence among goats so that $T$. gondii contamination can be avoided. It will also help to improve the economy of farmers by containment of T.gondii associated abortions in goats. Therefore the present work was carried out to assess the extent of Toxoplasma gondii infection in aborted goats from the central districts of Kerala by ELISA.

\section{Materials and Methods}

A total of 72 serum samples from goats belonging to the organised, unorganised and small holder farms that had aborted recently or had a history of abortion were collected from the central districts of Kerala viz., Palakkad, Thrissur and Ernakulam during the period from November 2019 to November 2020. Details of risk factors such as age, grazing behaviour of goats and stage of gestation were also collected to evaluate its significance on the presence of T. gondii antibodies. The serum samples were separated from the blood by centrifugation and stored at $-20^{\circ} \mathrm{C}$ until further processing.
All the serum samples were subjected to indirect ELISA for the detection of $\operatorname{lgG}$ antibodies of $T$. gondii using a commercial ELISA kit (IDEXX Toxotest, Switzerland). ELISA results were read using spectrophotometer at $450 \mathrm{~nm}$. Serum with sample to positive ratio $(\mathrm{S} / \mathrm{P})$ per cent which is equal or more than 100 per cent was considered as positive, serum with $\mathrm{S} / \mathrm{P}$ per cent between 30 to 100 was considered as weakly positive and serum with less than $30 \mathrm{~S} / \mathrm{P}$ per cent was considered as negative. The data was analysed statistically using $\mathrm{Chi}$ square test to ascertain the association of age, grazing behaviour and stage of gestation on the prevalence of $T$. gondii in goats.

\section{Results and Discussion}

Among the 72 serum samples examined, 31 (43 per cent) were found negative for the presence of $T$. gondii antibodies, whereas 13 (18 per cent) were weakly positive, and 28 (38.88 per cent) were detected to be highly positive for the presence of $T$. gondii specific antibodies (Table 1). The overall seroprevalence was determined to be 56.94 per cent. This is in accordance with the findings of Syamala and Devada (1999) who also recorded, 58.16 per cent seroprevalence in goats of Kerala.

A highly significant difference $(p<0$. 01 ) was noticed in the prevalence of $T$. gondii antibodies ingoats abovefouryears of age when compared to those of other age groups (Table 2). Thus it was inferred that the prevalence of T. gondii antibodies increased with increase in age. The ELISA results were in accordance with the study of Figueiredo et al. (2001), Figliuolo et al. (2004), Cavalcante et al. (2008), Kamani et al. (2010), Balea et al. (2012) and Hareendran (2017), who reported more number of animals above four years of age to be seropositive to $T$. gondii antibodies when compared to other age groups. This could be due to the continuous

Table 1. Seroprevalence of $T$. gondii in aborted goats by ELISA

\begin{tabular}{|l|c|c|c|c|c|c|}
\hline \multirow{2}{*}{$\begin{array}{c}\text { Samples } \\
\text { examined }\end{array}$} & \multicolumn{2}{|c|}{ Seronegative } & Weakly seropositive & \multicolumn{2}{c|}{ Seropositive } \\
\cline { 2 - 7 } & Number & Percentage & Number & Percentage & Number & Percentage \\
\hline 72 & 31 & 43 & 13 & 18 & 28 & 38.88 \\
\hline
\end{tabular}


Table 2. Age-wise seroprevalence of T. gondii

\begin{tabular}{|c|c|c|c|c|c|c|c|c|}
\hline \multirow{2}{*}{ Age(in years) } & \multirow{2}{*}{$\begin{array}{c}\text { No. of } \\
\text { samples } \\
\text { examined }\end{array}$} & \multicolumn{2}{|c|}{ Seronegative } & \multicolumn{2}{|c|}{$\begin{array}{c}\text { Weakly } \\
\text { Seropositive }\end{array}$} & \multicolumn{2}{|c|}{ Seropositive } & \multirow{2}{*}{ p value } \\
\cline { 3 - 8 } & & No. & $\%$ & No. & $\%$ & No. & $\%$ & \\
\hline <2 year & 20 & 18 & 90 & 1 & 5 & 1 & 5 & \\
\hline $2-4$ years & 28 & 8 & 28.57 & 9 & 32.14 & 11 & 39.28 & \multirow{2}{*}{$0.000^{*}$} \\
\hline$>4$ years & 24 & 5 & 20.83 & 3 & 12.5 & 16 & 66.66 & \\
\hline Total & 72 & 31 & 43 & 13 & 18 & 28 & 38.88 & \\
\hline
\end{tabular}

${ }^{*}$ Highly significant $(p<0.01)$

Table 3. Seroprevalence of $T$. gondii in goats related to grazing

\begin{tabular}{|c|c|c|c|c|c|c|c|c|}
\hline \multirow{2}{*}{ Grazing behaviour } & \multirow{2}{*}{$\begin{array}{c}\text { No. of } \\
\text { samples } \\
\text { examined }\end{array}$} & \multicolumn{2}{|c|}{ Seronegative } & \multicolumn{2}{|c|}{$\begin{array}{c}\text { Weakly } \\
\text { seropositive }\end{array}$} & \multicolumn{2}{|c|}{ Seropositive } & \multirow{2}{*}{$p$ value } \\
\hline & & No. & $\%$ & No. & $\%$ & No. & $\%$ & \\
\hline Regular grazing animals & 58 & 21 & 36.20 & 11 & 18.96 & 26 & 44.82 & \multirow{3}{*}{$0.046^{\star}$} \\
\hline Non grazing animals & 14 & 10 & 71.42 & 2 & 14.28 & 2 & 14.28 & \\
\hline Total & 72 & 31 & 43 & 13 & 18 & 28 & 38.88 & \\
\hline
\end{tabular}

*Significant difference $(\mathrm{p}<0.05)$

Table 4. Seroprevalence of T. gondii based on the stage of gestation

\begin{tabular}{|c|c|c|c|c|c|c|c|c|}
\hline \multirow{2}{*}{ Stage of gestation } & \multirow{2}{*}{$\begin{array}{c}\text { No. of } \\
\text { samples } \\
\text { examined }\end{array}$} & \multicolumn{2}{|c|}{ Seronegative } & \multicolumn{2}{|c|}{$\begin{array}{c}\text { Weakly } \\
\text { seropositive }\end{array}$} & \multicolumn{2}{|c|}{ Seropositive } & \multirow{2}{*}{ p value } \\
\cline { 5 - 10 } & 22 & 8 & 36.36 & 6 & 27.27 & 8 & 36.36 & \\
\hline First stage (<2months) & 28 & 4 & 14.28 & 4 & 14.28 & 20 & 71.42 & \multirow{2}{*}{$0.000^{*}$} \\
\hline $\begin{array}{c}\text { Second stage (2 to 3 } \\
\text { months) }\end{array}$ & 22 & 19 & 86.36 & 3 & 13.63 & 0 & 0 & \\
\hline $\begin{array}{c}\text { Third stage (4 months } \\
\text { and still birth) }\end{array}$ & 72 & 31 & 43.05 & 13 & 18.05 & 28 & 38.88 & \\
\hline Total & & & & & & & \\
\hline
\end{tabular}

${ }^{*}$ Highly significant $(p<0.01)$

Table 5. District - wise seroprevalence of toxoplasmosis

\begin{tabular}{|l|c|c|c|c|}
\hline District & No. tested & No. positive & \% positive & p value \\
\hline Thrissur & 41 & 23 & 56.09 & \multirow{2}{*}{$0.9^{\star}(\mathrm{ns})$} \\
\hline Palakkad & 15 & 8 & 53.33 & \\
\hline Ernakulam & 16 & 10 & 62.5 & \\
\hline
\end{tabular}

(Not significant - $p>0.05$ )

and prolonged exposure of aged animals to oocysts of T. gondii in the environment over the years. Repeated exposure from soil, feed and fodder results in the development of antibodies in the serum with high titres. Sharif et al. (2006) opined that the prevalence of toxoplasmosis in aged animals could be due to the browsing behaviour of goats. Goats generally browse the top of the grass and shrubs rather than taking the lower parts of the plants.
During the present study, positive correlation was observed between the prevalence of $T$. gondii antibodies in the serum samples of goats and their grazing habits. Out of 58 regular grazing animals, 44.82 per cent (26/58) were highly positive for $T$. gondii antibodies. Significant difference $(p<0.05)$ was noticed between the animals that were let out for grazing than those that were staged indoors (Table 3). This finding corroborated 
with that of Skjerve et al. (1998), where higher seroprevalence was noted in Norwegian lambs that were let out for grazing regularly. Similarly, Lahmar et al. (2015) noted a higher seroprevalence in Southern Tunisia sheep and goats that were let out for grazing.

Regular grazing makes the animals to come in close contact with the oocyst contaminated environment, which results in accidental ingestion. Repeated exposure to oocysts leads to infection and further development of serum antibodies. It is also worth mentioning that Kerala owing to its high humid weather, oocysts are protected against dessication thereby enabling their survival and sporulation.

A highly significant difference $(p<0.01)$ was noticed in the prevalence of $T$. gondii antibodies in goats that had aborted in the second stage when compared to the other stages (Table 4). Among the three stages of gestation, 71.42 per cent animals that had undergone abortion in the second stage of gestation were seropositive for $T$. gondii. According to Ahmed et al. (2008), foetal death was found to be caused by the multiplication of T. gondii in the placenta, rather than invasion of foetus by the parasite. The continuous multiplication of the parasite in the placenta and foetus could be enhanced by the local suppression of immune mechanism in the maternal placenta and immaturity of the foetal immune system. Moreover, it has been found that the inflammatory reactions induced in the placenta by T.gondii are capable of stimulating synthesis and release of prostaglandin $\mathrm{F} 2 \mathrm{a}$ which has a leuteolytic action leading to decreased progesterone level and subsequent abortion.

A relatively higher seroprevalence of toxoplasmosis was noticed in goats from Ernakulam district (62.5 per cent) followed by Thrissur (56.09 per cent) and Palakkad (53.33 per cent). Statistically, no significant difference could be noticed between the different districts and the positive results obtained (Table 5). The higher prevalence rate observed in Ernakulam could be due to the relatively less number of samples examined (16). Besides, the samples collected from Ernakulam were from goats reared in households and unorganised farms and were let out for grazing regularly. The presence of cat population in the premises of these houses and farms could also contribute to the results obtained. This finding corroborated with that of Figliuolo et al. (2004), where higher prevalence was noted in the household goats.

A high seroprevalence of 56.94 per cent was detected in recently aborted goats or those that had a history of abortion. This indicates that infection of T.gondii is widespread in this area. Hence, it is imperative to carry out a mapping of seroprevalence in goats in a wider geographical region in the state of Kerala to contain T. gondii contamination in the food chain to control zoonotic transmission. Adequate awareness must be created among goat farmers on the managemental aspects in order to control toxoplasmosis in goats.

\section{Acknowledgements}

This study has been carried out as part of Master's Research program and the financial support provided by Kerala Veterinary and Animal Sciences University is acknowledged.

\section{References}

Ahmed, Y.F., Sokkar, S.M., Desouky, H.M and Soror, A.H. 2008. Abortion due to toxoplasmosis in small ruminants. Global Veterinaria 2: 337-342.

Balea, A., Paştiu, A.I., Györke, A., Mircean, V. and Cozma, V. 2012. The dynamics of anti-Toxoplasma gondii antibodies (lgG) in small ruminants and pigs from Cluj County, Romania. Sci. Parasitol. 13: 163-168.

Cavalcante, A.C.R., Carneiro, M., Gouveia, A.M.G., Pinheiro, R.R. and Vitor, R.W.A. 2008. Risk factors for infection by Toxoplasma gondii in herds of goats in Ceará, Brazil. Arquivo Brasileiro de Medicina Veterinária e Zootecnia, 60: 36-41.

Dubey, J.P. and Beattie, C.P. 1988. Toxoplasmosis of animals and man. CRC Press, Inc., Boca Raton, Florida, 220p. 
Figliuolo, L.P.C., Rodrigues, A.A.R., Viana, R.B., Aguiar, D.M., Kasai, N. and Gennari, S.M. 2004. Prevalence of antiToxoplasma gondii and anti-Neospora caninum antibodies in goat from São Paulo State, Brazil. Small Rum. Res. 55: 29-32.

Figueiredo, J.F., Silva, D.A., Cabral, D.D. and Mineo, J.R. 2001. Seroprevalence of Toxoplasma gondii infection in goats by the indirect haemagglutination, immunofluorescence and immunoenzymatic tests in the region of Uberlandia, Brazil. Memorias do Instituto Oswaldo Cruz, 96: 687-692.

Hareendran, S.2017.Occurrence of Toxoplasma gondii in feline, caprine, human and environmental samples, M.V.Sc thesis, Kerala Veterinary and Animal Sciences University, Pookode, 92p.

Kamani, J., Mani, A.U. and Egwu, G.O. 2010. Seroprevalence of Toxoplasma gondii infection in domestic sheep and goats in Borno state, Nigeria. Trop. Anim. Hlth. Prod. 42: 793-797.
Lahmar, I., Lachkhem, A., Slama, D., Sakly, W., Haouas, N., Gorcii, M., Pfaff, A.W., Candolfi, E. and Babba, H. 2015. Prevalence of toxoplasmosis in sheep, goats and cattle in Southern Tunisia. $J$. Bact. Parasitol. 6: 1.

Sharif, M., Gholami, S.H., Ziaei, H., Daryani, A., Laktarashi, B., Ziapour, S.P., Rafiei, A. and Vahedi, M. 2006. Seroprevalence of Toxoplasma gondii in cattle, sheep and goats slaughtered for food in Mazandaran province, Iran, during 2005. Vet. J. 174: 422-424.

Skjerve, E., Waldeland, H., Nesbakken, T. and Kapperud, G. 1998. Risk factors for the presence of antibodies to Toxoplasma gondii in Norwegian slaughter lambs. Preventive Vet. Med. 35: 219-227.

Syamala, K. and Devada, K. Prevalence of caprine toxoplasmosis in Kerala. Proceedings of $11^{\text {th }}$ Kerala Science Congress; $27^{\text {th }}$ February to $1^{\text {st }}$ March, 1999, CPCRI, Kasaragod. pp. 154-157. 